\title{
Feasibility of Using Tillandsia usneoides L. as Biomass
}

\author{
Neeranoot Weerawong ${ }^{1}$, Natthaya C. van Beem ${ }^{2}$, and Kua-anan Techato ${ }^{1 *}$
}

\begin{abstract}
Spanish mosses (Tillandsia usneoides L.), a kind of decorative plant, is cheap and maintenance ease. The trimmed part should be considered as biomass. The Tillandsia usneoides L. which is called Spanish mosses in common name was used in this feasibility in order to be applied as biomass. The feasibility started with the calorific method for heating value. After that is the study of moisture content by gravimetric method. The component was also studied. The measurement of the growth of Spanish moss in term of length and weight were analyzed and compared to the properties of other biomasses. It is found that the heating value and moisture of Spanish moss from samples is $15.59 \mathrm{MJ} / \mathrm{kg}$ for calorific method, $34.80 \%$ for gravimetric method. The chemical components are $\mathbf{0 . 7 6 \%}(\mathrm{N})$, $\mathbf{4 2 . 8 6 \%}(\mathrm{C}), \mathbf{5 . 6 5 \%}(\mathrm{H})$, and $\mathbf{0 . 0 5 \%}$ (S) for elements in Spanish mosses. The growth of Spanish moss in length and weight of no water spray, water spray and fertilizer spray with average are 5.70, 14.33 and 10.51 gram per month, respectively. Spanish moss can grow well in the area which has moisture and light. In general, the Spanish mosses have good property to be biomass except the growth rate which is not fast.
\end{abstract}

Keywords - Spanish mosses (Tillandsia usneoides L.), heating value, biomass.

\section{INTRODUCTION}

$\mathrm{N}$ OWADAYS, the accommodations are mostly constructed as townhouses or condominium in Thailand. So the green area which is covered by plant is less available. The green roof or vertical green seems to be the solution for increasing the green area. The green roof or vertical green can be made by many kinds of plants. Some of plants are uncontrolled in growing up or not suitable to make the shading. The air plant is focused because of the growing up characteristic which is not soil needed. The Spanish moss is recommended for the green roof or vertical garden because it is cheap and not necessary to do frequent maintenance. Spanish moss has been proved to be an efficient atmospheric accumulator of the aerosols by the mechanism of phytoremediation [1].

The aim of the study is the idea to reduce waste from trimmed Spanish mosses. The trimmed waste was studied to be utilized as biomass for the production of energy based on renewable energy sources. Combustion is the main applied technology to produce heat and power from biomass and is generally economically feasible. The combustion of biomass as fuel has many environmental and economic advantages. The design and operation of biomass combustion systems rely

\footnotetext{
${ }^{1}$ Faculty of Environmental Management, Prince of Songkla University, Hatyai Songkhla, Thailand

${ }^{2}$ Faculty of Science, Thaksin University, Paphayom Phatthalung, Thailand
}

substantially on several biomass characteristics, namely, heating value, moisture, ash content and elemental composition [2]. The calorific value is the most important property of a fuel which determines the energy value which can be determined by experiment or calculated from ultimate and/or proximate analyses results of it

Spanish moss (Tillandsia usneoides L.) is an angiosperm which belongs to Bromeliaceae family Tillandsia genus [3]. It is colloquially known as "air plant" which grows upon tree branches or wire under the sun or partial shading area. Spanish moss has Trichome for absorbing moisture and nutrient in the air. Spanish moss is slow growing species plant and xerophyte which requires small amount of water for living. The photosynthesis is Crassulacean Acid Metabolism (CAM) as cactus which uses water very efficiently [4].

\section{METHODOLOGY}

1. Study and analyse the properties and chemical components CHONS, moisture content ASTM D3173, ash content ASTM D3286, and bomb calorimeter heating value of Spanish moss.

2. Measure the growth of Spanish moss by reporting in length and weight every month in 1 year-growth. The humidity and temperature of ambient are recorded as background data. The set of Spanish moss $1 \mathrm{~m}$ length was hung along 1 $m$ width on the rack (Fig.1).

3. Compare to the properties of other biomasses.

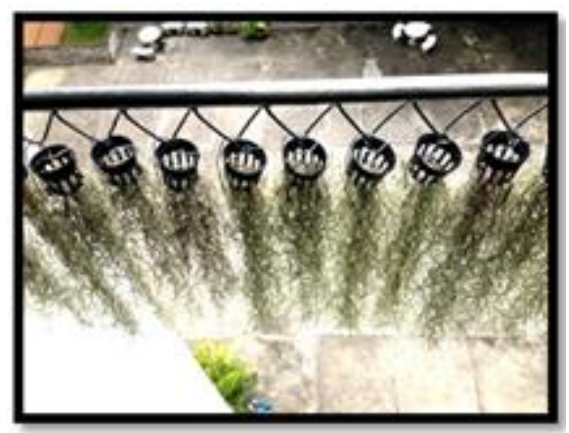

Fig.1: Sample set of Spanish moss

\section{RESUlT AND DisCUSSION}

The study found that that the heating value of Spanish moss from samples is $15.59 \mathrm{MJ} / \mathrm{kg}$ for calorific method, $34.80 \%$ for gravimetric method, and $8.84 \%$ for gravimetric method. The chemical components were $0.76 \%(\mathrm{~N}), 42.86 \%$ (C), $5.65 \%$ $(\mathrm{H}), 50.68 \%(\mathrm{O})$ and $0.05 \%(\mathrm{~S})$ in Spanish mosses. The appropriate to be biomass should not be more than $50 \%$. For 
the ash, if the heating value is high, the left ash is normally little and should not be more than $10 \%$. For Sulfur, the higher amount, the higher possibility of formation of Sulfur Dioxide.

The growths of Spanish moss in length and weight of no water spray, water spray and fertilizer spray with average were 5.70, 14.33 and 10.51 gram per month, respectively (Fig.2). The natural growing with only water is the best because of no overload of fertilizer.

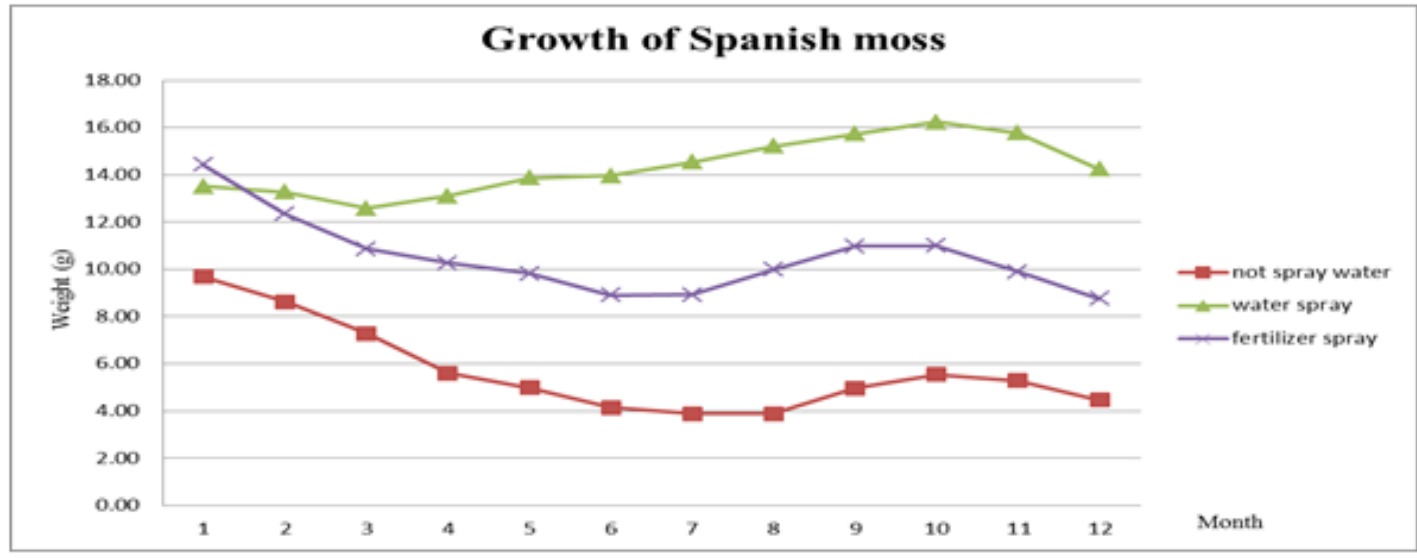

Fig. 2: Growth of the Spanish moss

The heating value and moisture content of Spanish moss is close to the rice husk, bagasse, wood chip, and straw. The component in view of $\mathrm{C}, \mathrm{H}, \mathrm{O}, \mathrm{N}$, and $\mathrm{S}$ is also close to general biomass.

\section{CONCLUSION}

The Spanish moss can be used as biomass but the property of growth retardant must be concerned. The Spanish moss should be used as supplementary biomass but not expected to be the major part for the power plant. If the fixed amount of Spanish moss is known, it can be calculated back to the amount of the plant grown around the building. Nevertheless the study must know the amount of scraps of Spanish moss that occurs from the maintenance trimming in order to be the supply for a very small power plant or co-firing with other biomass.

\section{ACKNOWLEDGMENT}

- This Research was Faculty of Environmental Management, Prince of Songkla University

- This Research was supported by Research and Researchers for Industries-RRI.

\section{REFERENCES}

[1] Sutton T.K., Cohen R.A. and Vives, S.P. 2014. Evaluating relationships between mercury concentrations in air and in Spanish moss (Tillandsia usneoides L.). Ecological Indicators, 36: 392-399. http://dx.doi.org/10.1016/j.ecolind.2013.08.011

[2] Erol M., Haykiri-Acma H.and Küçükbayrak S. 2010. Calorific value estimation of biomass from their proximate analyses data. Renewable Energy, Volume 35, Issue 1, Pages 170-173 http://dx.doi.org/10.1016/j.renene.2009.05.008

[3] George J., Husk, and John F. 2004. Mineral dynamics in Spanish moss, Tillandsia usneoides L. (Bromeliaceae), from central Florida, USA, Science of the Total Environment, 321: 165-172. http://dx.doi.org/10.1016/j.scitotenv.2003.09.001

[4] Wannaz E.D., Carreras H.A., Perez C.A. and Pignata M.L. 2006. Assessment of heavy metal accumulation in two species of Tillandsia in relation to atmospheric emission sources in Argentina. Sci. Total Environ, 361: 267-278.

http://dx.doi.org/10.1016/j.scitotenv.2005.11.005 